\author{
Anna ŚWIERCZEWSKA-GĄSIOROWSKA, PhD* Review Scientific Article \\ Police Academy in Szczytno, Poland \\ Received: 5 October 2020 \\ Monika PORWISZ, PhD ${ }^{* *}$ \\ Police Academy in Szczytno, Poland \\ Accepted: 27 November 2020 \\ UDK: 343.13(438) \\ 351.74(438) \\ Pawet OLBER, PhD ${ }^{\text {**** }}$ \\ https://doi.org/10.47152/rkkp.58.3.5 \\ Police Academy in Szczytno, Poland
}

\title{
ESPOZ - AN ELECTRONIC SYSTEM SUPPORTING THE POLISH POLICE IN THE SEARCH FOR MISSING PERSONS ${ }^{* * * *}$
}

The Police Academy in Szczytno has been carrying out a research project entitled "Development of a database and tools for semantic search for information and knowledge management in the area of missing persons and search for persons", financed from the funds of the National Centre for Research and Development for national defence and security.

The objective of the conducted research project is to prepare a database and a tool for semantic search for information and knowledge management in the area of missing persons and search for persons, as well as to equip the Polish Police with a technologically advanced tool for semantic and contextual search for information on standards, rules,

\footnotetext{
* e-mail: a.swierczewska@interia.pl

** e-mail:m.porwisz@wspol.edu.pl

**** e-mail: p.olber@wspol.edu.pl

**** This article is prepared as part of the project entitled "Development of a database and tools for semantic search for information and knowledge management in the area of missing persons and search for persons", No. DOB-BIO9/12/01/2018. Project is financed by the National Centre for Research and Development under the competition 9/2018 for the execution and financing of projects in the field of scientific research or development work for the benefit of national defence and security. The project is carried out in a consortium by the Police Academy in Szczytno (leader), Jarosław Dąbrowski Military University of Technology and the entrepreneur Transition Technologies S.A.
} 
good practices and specific patterns of behaviour in the area of searching for missing persons.

The final effect of the mentioned research project is the eSPOZ system of searching for missing persons, which is described in the article.

\section{Key words: search for missing persons, semantic search, se- arch process, Police, search and rescue groups.}

\section{Introduction}

In order to precisely determine the scope of the publication in question, it is reasonable to separate the notion grid relating to the search for persons. Clarification of the term search is necessary because the phrase "search for a person" in the language layer can be interpreted in two ways: as searching for a missing person or searching for a person hiding from law enforcement agencies and the judiciary. The legal basis, procedure and scope of activities undertaken by law enforcement authorities with regard to the above mentioned categories of persons are different. This is not only an apparent problem, as often the use of the term "search for a person" may evoke connotations with a person who is not missing, but is hiding from law enforcement agencies. There is also the term 'enforced disappearance', which is used in the context of methods used in Latin American countries in the 1960s and 1970s to fight political opponents. In the countries of this region, mass kidnappings of people suspected of opposition activities were carried out on behalf of the authorities (Domagała, 2017: 45). This kind of disappearance in international law ${ }^{1}$ is the sum of violations of fundamental rights such as the right to life, freedom and torture and is treated as a crime (Baranowska, 2017: 49). Therefore, it should be clearly stated that the subject of this publication is the search for missing persons in the Polish legal system.

According to the International Convention for the Protection of All Persons from Enforced Disappearance (ICPPED), "enforced disappearance is considered to be the arrest, detention, abduction or any other form of deprivation of liberty by agents of the State or by persons or groups of persons or groups of persons acting with the authorization, support or acquiescence of the State, followed by a

1 The European Court of Human Rights on enforced disappearances concerning Bosnia and Herzegovina, Croatia, Russia, Spain and Turkey has held that enforced disappearances amount to violations of Articles 2 (right to life), 3 (prohibition of torture), 5 (right to liberty and security of person) and 13 (right to an effective remedy) of the European Convention on Human Rights. For more on this, see: G. Citroni, Missing persons and victims of enforced disappearance in Europe, Council of Europe 2016, s.6, https://rm.coe.int/missing-persons-and-victims-of-enforced-disappearance-ineurope-issue-/16806daa1c, accessed on: 5.07.2020. 
refusal to acknowledge the deprivation of liberty or by concealment of the fate or whereabouts of the disappeared person, which place such a person outside the protection of the law"2. The presented definition clearly highlights the difference between missing persons (as commonly understood) and missing persons who are victims of the practice of enforced disappearance. Bearing in mind that the problem of enforced disappearances is a very important in the modern world, it should be pointed out that the eSPOZ system is to cover all missing persons whose status and fate is unknown. This approach is in line with the definition of a missing person in Polish law, according to which any person who, as a result of an event that makes it impossible to determine his or her whereabouts, must be found in order to ensure the protection of his or her life, health or freedom, is considered a missing person ${ }^{3}$.

\section{Missing persons in Poland - statistics}

Undertaking research on searching for missing persons was dictated by the scale of recorded cases. Every year, the Polish Police register about 20,000 reports of missing persons, of which about 6,000 concern missing children. Alarming statistics on missing persons make us reflect on the causes of missing persons and on the effectiveness of the searches conducted by the Polish Police. The following are the statistics (in tabular terms) of missing persons in Poland in 2013-2017.

Table 1. Number of reported missing persons in the year

\begin{tabular}{|c|c|}
\hline Year & Total \\
\hline 2017 & 19563 \\
\hline 2016 & 19445 \\
\hline 2015 & 20458 \\
\hline 2014 & 20845 \\
\hline 2013 & 19617 \\
\hline
\end{tabular}

2 International Convention for the Protection of All Persons from Enforced Disappearance, United Nations, https://treaties.un.org/doc/Publication/CTC/Ch_IV_16.pdf, accessed on: 9.11.2020.

3 Zarządzenie nr 48 Komendanta Głównego Policji z dnia 28 czerwca 2018 r. w sprawie prowadzenia przez Policję poszukiwania osoby zaginionej oraz postępowania w przypadku ujawnienia osoby o nieustalonej tożsamości lub znalezienia nieznanych zwłok oraz szczątków ludzkich, https:// isp.policja.pl/isp/aktualnosci/prawo/13434,Zarzadzenie-nr-48-Komendanta-Glownego-Policji-zdnia-28-czerwca-2018-r.html, accessed on: 9.11.2020.

4 The Polish Police statistics, http://statystyka.policja.pl/st/wybrane-statystyki/zaginieni/50885,Zaginieni. html, accessed on: 17.07.2020. 
Table 2. Missing children reported to the Police

\begin{tabular}{|c|c|c|c|}
\hline Year & Up to 7 years & $\mathbf{7 - 1 3}$ years & $\mathbf{1 4 - 1 7}$ years \\
\hline 2017 & 443 & 953 & 5362 \\
\hline 2016 & 490 & 980 & 5475 \\
\hline 2015 & 535 & 1022 & 6232 \\
\hline 2014 & 525 & 964 & 6615 \\
\hline 2013 & 481 & 951 & 6121 \\
\hline
\end{tabular}

\section{Challenges and difficulties in searching for missing persons}

Despite this high number of disappearances, nearly $90 \%$ of missing persons are found in the first hours immediately after receiving a report. Finding the remaining $10 \%$ takes more than one day. Nevertheless, the scale of missing persons in Poland forces many different initiatives aimed at increasing the effectiveness of the Police. Within the structures of law enforcement bodies there is no database system for analysing the cases of missing persons carried out so far. Thus, the existing state of affairs results in the lack of possibility of quick, automatic and systemic correlation of data and information from current cases in relation to previous cases. There is also a lack of technological solutions facilitating decision making in situations of missing persons, which are characterized by many difficulties and challenges.

The main problems identified in the area of searching for missing persons concern the formal and legal aspects of these activities, including determining the level of the search, determining the cause of a missing person and indicating the appropriate methodology of the planned activities.

As far as formal and legal aspects are concerned, it should be emphasized that the Polish legal system has three levels of searching for a missing person depending on the risk of threat to life, health or freedom of a person. The search level is the degree determining the urgency and scope of undertaking search activities depending on the identified risk of threat to life, health or freedom of a missing person. The level of the search is determined by many factors. Factors that imply a given category of search are: age of a person, condition of health, suspicion of committing a crime against life, freedom, suicidal intentions, weather conditions. Formal determination of the search level adequate to the circumstances of a person missing helps to plan and carry out search activities so that they are as effective as possible. 
The level of the search shall be assigned according to the degree of threat to the life, health or freedom of a missing person. And so in the case of :

- Level I - the threat to the life, health or freedom of a missing person must be real and direct,

- Level II - there is a reasonable suspicion of risk to the life, health or liberty of a missing person,

- Level III - a person missing is not connected with an immediate and justified threat to his life, health or freedom.

The common element in all the cases mentioned above is the existence of a threat to life, health and freedom of a missing person. However, the above premise requires clarification. The occurrence of a threat can be interpreted as the occurrence of a situation, a condition threatening the loss of life, health, freedom and should be associated with a situation in which there is a high degree of probability of specific consequences for a missing person. There must therefore be circumstances which, when assessed objectively and reasonably, are such as to indicate the existence of a threat. The existence of a threat should be confirmed by specific information gathered in the case. There are no restrictions on the sources of a threat. These can be both third parties and environmental (including weather) conditions.

With regard to the determination of the cause of a person missing and the search methodology, it is necessary to use expert opinions of specialists on the behaviour of particular groups of people suffering from mental dysfunctions in a situation of getting lost, loneliness and ways of establishing contact and communication with these people. For the purposes of the eSPOZ system (Polish system of searching for missing persons), an expert's report has been developed, which describes mental disorders, which are known to determine the occurrence of specific behaviours of a missing person. The expertise was prepared taking into account the international classification of disorders and diseases of ICD-105.

\section{Polish system for searching for missing persons eSPOZ}

The answer to the identified challenges and difficulties in searching for missing persons in Poland is the eSPOZ system being developed, which is a systemic solution to the problem. Although the system is intended solely for the Police, it can also be considered a social project which will bring tangible benefits

5 https://icd.who.int/browse10/2016/en, accessed on: 20.07.2020. 
to the whole society. Therefore, the development of the eSPOZ system is part of the catalogue of system solutions which, in the opinion of (M. Henderson, P. Henderson, Kiernan, 2000: 6), are particularly important in case of searching for missing persons. It is also expected that this system will significantly contribute to the reduction of social and economic costs connected with searching for missing persons.

Works on the eSPOZ system have been preceded by extensive consultations with experts as well as representatives of search and rescue groups, which support the Police in conducting search for missing persons in the open area. It has been decided that such an approach will allow to determine the needs of users in the scope of the created technology and will allow to highlight the decision-making processes at various stages of the process of searching for missing persons. (K. Harrington et. al, 2018: 674) confirm that the approach taken is correct. It provides knowledge of best practices in searching for missing persons and can be a valuable source of information on the design of tools to support decision making and identify the needs of future users of technology supporting the tracing of missing persons.

\subsection{Description of the eSPOZ system}

Officers and employees of organizational units of the Polish Police, competent in matters of searching for missing persons will be the users of the eSPOZ IT system. The system will enable them to enter data from current proceedings as well as information from archival cases. From the end user's point of view, the basic application will be the system (actually an interface) used for entering and administering data in cases related to missing persons. From this level, an application user will be able to call up other advanced services provided by separate system components, such as the semantic search module, geolocation inference module and network analysis module. A detailed functional division of the application and its components is shown in the figure below:

The scope of data processed by the eSPOZ system has been defined by individual components of the graphical user interface. Due to the extensive range of data collected and processed in each case, the graphic interface was divided into four main parts (screens). Individual application screens contain specific sections and data range fields. The eSPOZ application interface enables entering data concerning current issues, managing issues saved in the system, optimal planning of searches and management of dictionaries containing values processed by the system. The necessity of entering data in particular parts of the graphical interface will depend on the type of a search case. The main interface of the eSPOZ application is presented in the figure below: 
Figure 1. Components of the eSPOZ system.

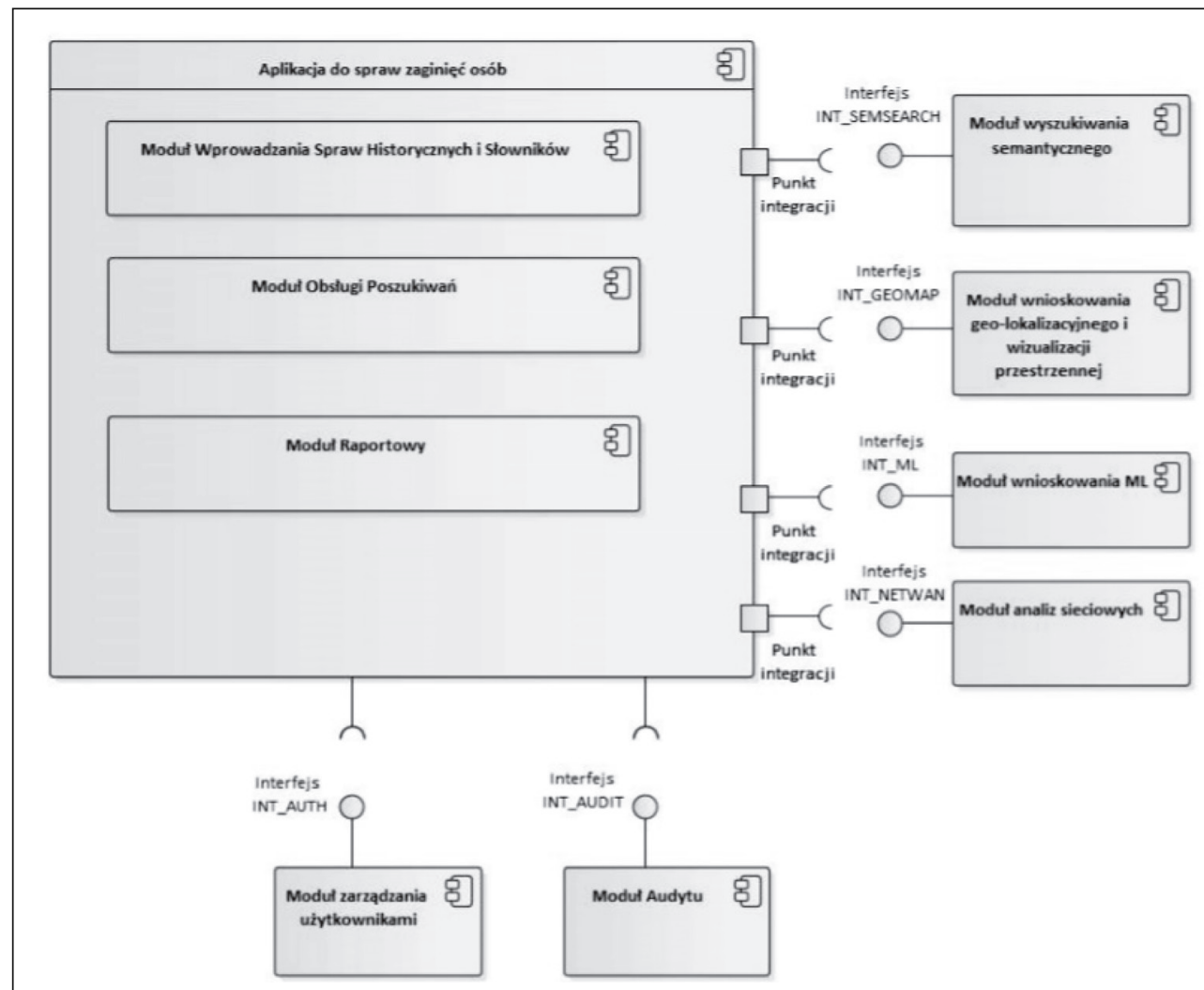

Figure 1 description:

- Aplikacja do spraw zaginięć osób - Missing Persons Application

- Moduł wprowadzania spraw historycznych - Module for entering historical cases

- Moduł obsługi poszukiwań - Search Processing Module

- Moduł raportowy - Reports module

- Moduł zarządzania użytkownikami - User authentication module / INT_AUTH interface

- Moduł audytu - Audit module - INT_AUDIT interface

- Moduł wyszukiwań semantycznych - Semantic search module / INT_SEMSEARCH Interface

- Punkt integracji - Integration point

- Moduł wnioskowania geo-lokalizacyjnego i wizualizacji przestrzennej-Geomapping request and spatial visualization module / INT_GEOMAP interface

- Moduł wnioskowania ML - ML request module / INT_ML interface

- Moduł analiz sieciowych - Network analysis module / INT_NETWAN interfact 


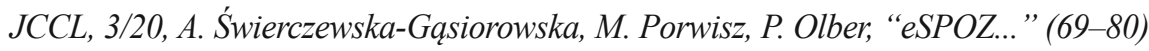

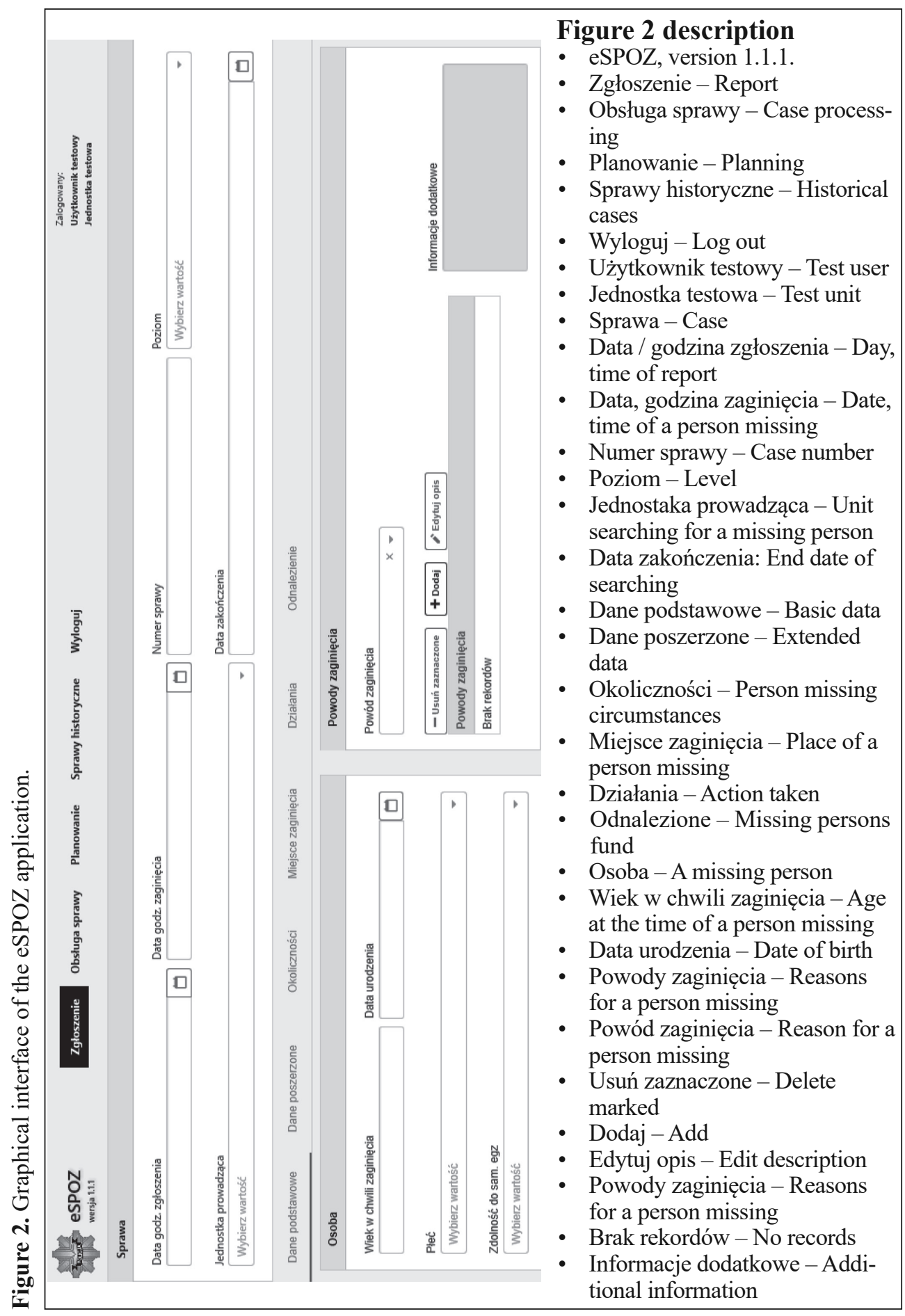


On the basis of data collected and processed in the eSPOZ system, concerning both the current case and historical data, the system will offer hints that will help a system user to make a decision on further actions concerning a given exploration case. The hints obtained by a system user should contribute to optimization of the process of searching for a missing person and, as a result, to finding him/her in the shortest possible time. Immediate making of the right decisions is particularly important as the first hours are extremely important for a missing person who may be in danger. As time goes by, the accuracy of evidence provided by a person informing about as missing person decreases as well (Jacobo, 2018).

\subsection{Searching for a missing person planning in the eSPOZ system}

As a rule, law enforcement authorities have appropriate procedures in place to deal with the missing person information. They first verify the information received and then decide how to allocate appropriate forces and resources (Jacobo, 2018). However, such a procedure involves a subjective assessment of the situation and the possibility of making mistakes at the stage of preliminary actions.

In order to completely eliminate the above mentioned situations, the eSPOZ application has been equipped with the functionality of requesting the level of search for a missing person. The eSPOZ system also makes a selection of the cause of a person missing based on the assessment of potential causes of a person missing (murder, suicide, getting lost, kidnapping, escape).

In order to make an appropriate decision on the follow-up of searches for missing persons, the eSPOZ application will contain appropriate procedures to be displayed to a system user on the basis of keywords entered or specific data contained in the search case questionnaire. It is assumed that these procedures will be continuously adapted and improved. Presently, the procedures contained in the eSPOZ system are in line with the principles contained in the Guiding Principles for the Search for Disappeared Persons adopted in 2019 by the UN Committee 6 . According to these rules the search for a person should be inter alia conducted under the assumption that the missing person is still alive. The search should respect the right to participation, human dignity, follow a differential approach and be coordinated, interrelated, carried out safely, independent, impartial, governed by a public policy and protocols. All these requirements, and others contained in the document, were taken into account

6 Guiding principles for the search for disappeared persons, https://www.ohchr.org/_layouts/15/WopiFrame.aspx?sourcedoc=/Documents/HRBodies/CED/CED_C_7_E_FINAL.docx\&action=default \&DefaultItemOpen=1, accessed on: 09.11.2020. 
when developing the system. It is important that the eSPOZ system will have the functionality of previewing the history of changes in particular procedures, together with a description of changes made, date of a change and its author.

\subsection{Knowledge base of the eSPOZ system}

The basis for the operation of the eSPOZ system will be current information concerning each new case of a person missing and a knowledge base containing instances describing historical cases of a person missing. Each new reported case of a person missing will require a search of the ontology and search for identical cases based on a description of the current case in the following order:

1. Formulation of a question consisting of one or more basic concepts.

2. Designation of cases written in the ontology, matching the current case.

3. Determining an extent to which cases fit.

4. Defining a ranking of case descriptions in the resultant set.

5. Building a resultant set.

However, searching for identical cases requires a large collection of information. Therefore, the vast majority of instances recorded in the knowledge base will describe the cases in which a missing person was found and the reason for missing.

\subsection{Reporting in the eSPOZ system}

The eSPOZ system has the functionality of generating reports and statistical data on conducted search cases. For this purpose the system uses a specific information range in the form of a set of analytical objects, facts and dimensions and links between these objects. It is assumed that generating statistical data in the scope of searching for missing persons in Poland will allow to get to know precisely the scale of the phenomenon and to improve search procedures. As Henderson writes, the frequency of occurrence of missing persons is at least as high as the frequency of other issues, which usually arouse much greater interest of the media and public opinion (M. Henderson, P. Henderson, Kiernan, 2000: 2). It should therefore be recognised that the functionality of generating reports and statistical data is a key element of the eSPOZ system.

\section{Future research work}

There is generally little information available on the course of search activities and their effectiveness. There is therefore a critical need to monitor, 
investigate and evaluate these activities in order to minimise the impact and consequences of persons missing. Henderson claims that recurring incidents, relationship between homelessness and missing persons and the effectiveness of educational programmes are important areas to be investigated in the future (M. Henderson, P. Henderson, Kiernan, 2000: 6). Finding ways to reduce, or preferably avoid, social and economic costs associated with search for missing persons must be undertaken by a community, government, NGOs, organisations, business sector, media, but also by missing persons themselves who have been found.

\section{Summary}

There are various solutions in the world supporting search for missing persons. For example (Ferreira et al., 2018: 241) describe the Myosotis system, and indicate other technologies used in the search of missing persons, which take into account the specifics of individual countries and meet certain formal and institutional requirements.

In Poland, until now, the search for missing persons has been carried out without the support of advanced IT systems. However, specialised police departments dealing with the search for missing persons need to quickly update their knowledge on the actions taken (Ferreira et al. 2018: 239). According to the authors, the eSPOZ system developed in Poland is such a solution. We expect that this system will eliminate the problems and difficulties identified so far in searching for missing persons:

- will help to avoid mistakes during the classification of missing persons, which affects the scope of undertaken actions,

- will allow for the observance and implementation of all activities that are elements of the existing rules, including, among others, publishing images of missing persons, carrying out checks in hospitals, collecting biological material

- will improve cooperation with other entities whose activities have an impact on the effectiveness of search, in particular with municipal guards and voluntary search and rescue groups,

- will enable effective supervision of the exploration activities carried out

- will improve cooperation between the Police and the prosecutor's office in identifying the dead body,

- will optimize the circulation of information on disappearances outside the country by promoting the electronic exchange of information,

- increase the competence of police officers in searching for missing persons. 


\section{Bibliography}

- Baranowska, G. (2017) Wymuszone zaginięcia w Europie. Ksztattowanie się międzynarodowych standardów zapobiegania i egzekwowania odpowiedzialności państw. Warszawa: Wydawnictwo C.H. Beck.

- Citroni G., (2016) Missing persons and victims of enforced disappearance in Europe. France: Council of Europe.

- Domagała, P. (2017) Międzynarodowa konwencja ONZ w sprawie ochrony wszelkich osób przed wymuszonym zaginięciem. Perspektywa Polska. Warszawa: Wydawnictwo C.H. Beck.

- Ferreira, R. et. al (2018) Myosotis: An Information System Applied to Missing People Problem. In: SBSI'18: Proceedings of the XIV Brazilian Symposium on Information Systems, pp. 239-245.

- Guiding Principles for the search for disappeared persons, adopted on the 16th Session of the Committee on Enforced Disappearances, 16th April 2019. International Convention for the Protection of all Persons from Enforced Disappearance, adopted on 20 December 2006 during the sixty-first session of the General Assembly in resolution A/RES/61/177. Available at: https://icd.who. int/browse10/2016/en, accessed on: 20.07.2020.

- Harrington K. et. al. (2018) Decision-making within missing person search. Cognition, Technology \& Work, 4(20), pp. 665-680. https://doi.org/10.1007/ s10111-018-0515-x

- Henderson, M., Henderson, P., Kiernan, C. (2000) Missing Persons: Incidence, Issues and Impacts, Trends \& Issues in Crime and Criminal Justice, 144, pp. 1-6.

- Jacobo J. (2018) Why the first 72 hours in a missing persons investigation are the most critical, according to criminology experts, https://abcnews.go.com/ US/72-hours-missing-persons-investigation-critical-criminology-experts/ story?id=58292638, accessed on: 20.07.2020.

- Komendanta Głównego Policji, Zarządzenie nr 48 z dnia 28 czerwca 2018 r. w sprawie prowadzenia przez Policję poszukiwania osoby zaginionej oraz postępowania w przypadku ujawnienia osoby o nieustalonej tożsamości lub znalezienia nieznanych zwłok oraz szczątków ludzkich, https://isp.policja.pl/ isp/aktualnosci/prawo/13434,Zarzadzenie-nr-48-Komendanta-GlownegoPolicji-z-dnia-28-czerwca-2018-r.html, accessed on: 9.11.2020.

- Statistical data of the Polish Police, http://statystyka.policja.pl/st/wybranestatystyki/zaginieni/50885,Zaginieni.html, accessed on: 17.07.2020. 